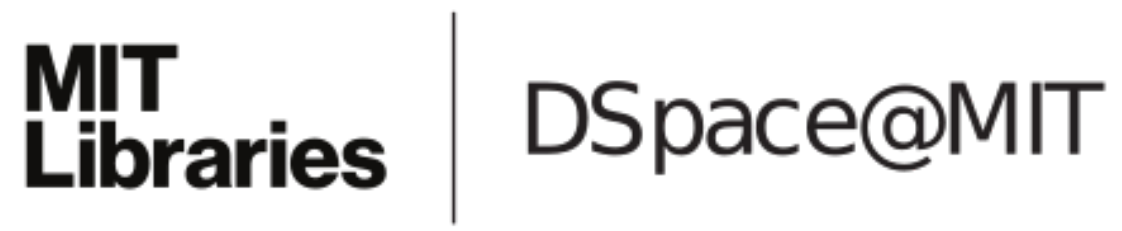

MIT Open Access Articles

Free Innovation by Consumers-How Producers Can Benefit Consumers' free innovations represent a potentially valuable resource for industrial innovators

The MIT Faculty has made this article openly available. Please share how this access benefits you. Your story matters.

Citation: von Hippel, Eric. "Free Innovation by Consumers - How Producers Can Benefit." Research-Technology Managment 60.1 (2017): 39-42.

As Published: http://www.tandfonline.com/doi/full/10.1080/08956308.2017.1255055

Publisher: The Industrial Research Institute

Persistent URL: http://hdl.handle.net/1721.1/110665

Version: Author's final manuscript: final author's manuscript post peer review, without publisher's formatting or copy editing

Terms of use: Creative Commons Attribution-Noncommercial-Share Alike 


\section{Free Innovation by Consumers-How Producers Can Benefit}

\section{Eric von Hippel Research Technology Management (2017)}

Consumers develop many valuable products-and reveal their unprotected designs to others — as "free innovations." 1 These free innovations represent a potentially valuable resource for industrial innovators. Rather than replicating the innovation process already undertaken by these consumer innovators, producers can collect and evaluate consumer designs to identify those with the highest profit potential and apply their R\&D dollars to refining these designs. They may also continue to develop products in areas where consumers are not actively innovating, but that are valuable to the business. In other words, to benefit from free innovation, producers must learn to engage in a new division of labor with consumers.

There is a massive amount of free innovation in modern economies; studies in six countries show that tens of millions of people in the household sector-consumersspend tens of billions of dollars each year to develop and improve products to make their own lives better (Table 1). These individuals, who might also be called "consumer innovators,” develop consumer products and services for reasons ranging from personal need, to simple enjoyment of the development process, to a desire to help others. The market in which these consumer innovators operate is an important innovation segment: consumer products and services account for the largest proportion of GDP in most countries; between 60 and 70 percent of GDP in the United States and other OECD nations is devoted to products and services intended for final consumption (Mataloni 2015; OECD 2015).

Table 1.-Consumer innovators in six countries

\begin{tabular}{lcccccc}
\hline $\begin{array}{l}\text { Country } \\
(n)\end{array}$ & $\begin{array}{c}\text { UK } \\
(1173)\end{array}$ & $\begin{array}{c}\text { US } \\
(1992)\end{array}$ & $\begin{array}{c}\text { Japan } \\
(2,000)\end{array}$ & $\begin{array}{c}\text { Finland } \\
(993)\end{array}$ & $\begin{array}{c}\text { Canada } \\
(2,021)\end{array}$ & $\begin{array}{c}\text { South } \\
\text { Korea } \\
(10,821)\end{array}$ \\
\hline $\begin{array}{l}\text { \% of } \\
\text { consumers }\end{array}$ & & & & & & \\
$\begin{array}{l}\text { who engage } \\
\text { in consumer } \\
\text { innovation }\end{array}$ & $6.1 \%$ & $5.2 \%$ & $3.7 \%$ & $5.4 \%$ & $5.6 \%$ & $1.5 \%$ \\
$\begin{array}{l}\text { Number of } \\
\text { consumer } \\
\text { innovators }\end{array}$ & $\begin{array}{c}2.9 \\
\text { million }\end{array}$ & $\begin{array}{c}16.0 \\
\text { million }\end{array}$ & $\begin{array}{c}4.7 \\
\text { million }\end{array}$ & $\begin{array}{c}0.172 \\
\text { million }\end{array}$ & $\begin{array}{c}1.6 \\
\text { million }\end{array}$ & 0.54 million \\
\hline Sour:vion
\end{tabular}

Source: von Hippel (2017), Table 2-1, p.21

Note: Surveys included individuals over 18 years of age; individuals younger than 18 were excluded due to youth privacy concerns. In Finland, the age range of respondents was 18-65 years.

Examples of free innovation by users and communities abound; in recent years, this kind of innovation has been spurred by increasing access to free information and low-cost 
design tools, largely via the Internet, and by the emergence of a seemingly endless variety of online communities where innovators can connect and collaborate. For example, NightScout, a system that monitors diabetics' blood sugar levels through the night, was developed by a community of consumers dedicated to addressing problems associated with Type 1 diabetes. Many of the participants in this community either have Type 1 diabetes themselves or have children who do. NightScout's story, as told by Linebaugh (2014) is emblematic of the phenomenon:

NightScout got its start in the Livonia, N.Y., home of John Costik, a software engineer at the Wegmans supermarket chain. In 2012, his son Evan was diagnosed with Type 1 diabetes at the age of four. The father of two bought a Dexcom continuous glucose monitoring system, which uses a hair's width sensor under the skin to measure blood-sugar levels. He was frustrated that he couldn't see Evan's numbers when he was at work. So he started fiddling around.

On May 14 last year [2013], he tweeted a picture of his solution: a way to upload the Dexcom receiver's data to the Internet using his software, a \$4 cable and an Android phone.

That tweet caught the eye of other engineers across the country.

One was Lane Desborough, an engineer with a background in control systems for oil refineries and chemical plants whose son, 15, has diabetes. Mr. Desborough had designed a home-display system for glucose-monitor data and called it NightScout. But his system couldn't connect to the Internet, so it was merged with Mr. Costik's software to create the system used today. ...

Users stay in touch with each other and the developers via a Facebook group set up by Mr. Adams. It now has more than 6,800 members. The developers are making fixes as bugs arise and adding functions such as text-message alarms and access controls via updates.

Dexcom Corporation, the glucose monitor manufacturer mentioned in the story, has learned from the NightScout design and has since added identical functionality to its products. Dexcom's management sees these new features as a valuable addition to the company's commercial offerings.

How can consumers justify investing their time and resources in developing valuable innovations like these, when no one pays for either their labor or their freely revealed designs? The answer is relatively simple: rather than seeking financial rewards, free innovators reward themselves in other ways: through their own use of their innovation, which enhances their own lives; through the enjoyment and learning they gain from their innovation projects; and through other forms of self-reward. Free innovators don't need or expect to be paid for their time because they are driven by other motivators (von Hippel 2017, p. 29). 


\section{Challenging the Producer Innovation Paradigm}

Free innovation, or consumer innovation, challenges the dominant paradigm for innovation, the producer innovation paradigm, which has shaped innovation thinking for decades. Free innovation development and diffusion processes are very similar to those for open-source software development — and very different from traditional commercial product development processes. Free innovators start a project, generally based on a personal need or interest (Figure 1, top). They work on it, unpaid, during nights and weekends or other personal discretionary time. Again, they are willing to do this because they seek other rewards for their efforts - whether the benefits of use, learning, or just personal enjoyment. Often, as the project is developing, the innovator will share the project with others, usually via the Internet. Others then may join the project, also unpaid, to contribute to its development and help move it forward. When the project is finished, its outcomes are freely revealed to anyone-consumers or producers - who wants to adopt the design for use or sale.

Figure 1.-The free innovation and producer innovation paradigms

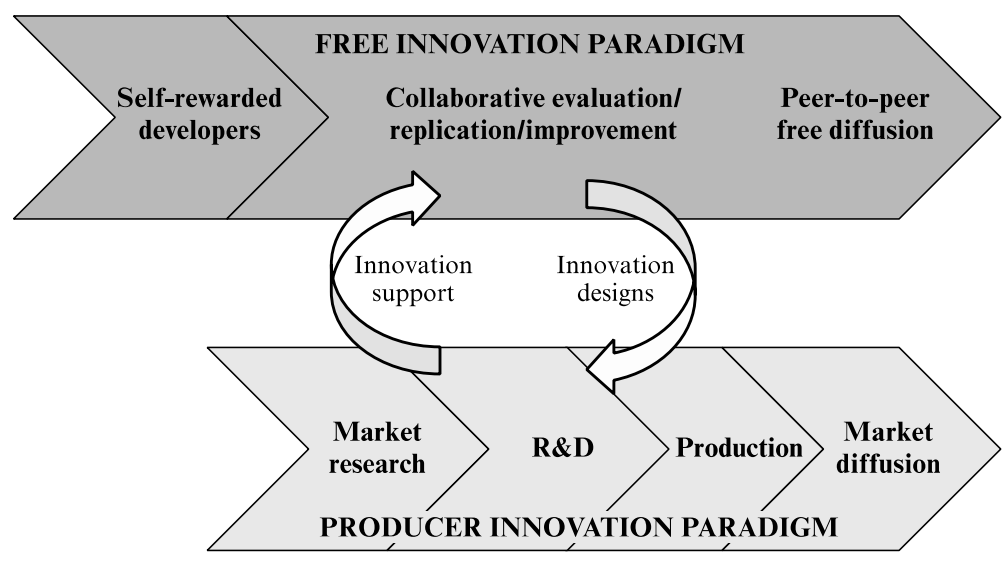

By contrast, in the traditional commercial innovation paradigm (Figure 1, bottom), innovation is carried out by paid employees of a firm or by entrepreneurs seeking profit. Producer development projects begin by identifying a need in the general market—an external need - and proceeds through defined stages of research, development, and production. The firm protects its finished design from free adoption by rivals in order to protect its profit potential.

On the basis of these two descriptions, the fundamental contrasts between free innovation and standard producer development processes and development paradigms should be very clear. What may be less clear is the difference in scale: millions of consumers-29 million in the United Kingdom alone-engage in free innovation, while commercial producers in the United Kingdom employ only about 22,000 full-time product developers - a ratio of more than 100 free innovators to 1 commercial product developer (von Hippel, de Jong, and Flowers 2012, p. 1676). 


\section{Integrating Free Innovation into the Corporate Innovation Pipeline}

In recent years, a connection has evolved between the two innovation paradigms, as forward-thinking companies seeking new ideas and new markets have begun to engage and collaborate with free innovators and their communities, to the benefit of both. In general, companies have built these links by providing support of various types to innovation communities or individual innovators and by adopting free innovator designs as part of product offerings.

My collaborators and I have undertaken studies of these interactions in fields ranging from sporting goods, to toys, to retail banking services (Franke, von Hippel, and Schreier 2006; Oliveira and von Hippel 2011; Antorini, Muñiz, and Askildsen 2012). That work has identified five more or less distinct ways that producers can collaborate with and benefit from the free innovation phenomenon:

1. Learning from free innovator pioneering

2. Supporting free innovator development of complements to commercial products

3. Accessing free innovator product designs to reduce in-house development costs

4. Directing free innovator effort to particular areas or approaches through tools and other support

5. Using competition from free designs to spur improvements to commercial products

Learning from Free Innovator Pioneering. Free innovators tend to be first moversour research has found that, in general, free innovators, not producers, are the ones who pioneer new markets and product types - a finding reflected in the figure by the positioning of the free innovation representation further to the left than the producer innovation model. Free innovators can afford to take a pioneering role because they are concerned only with their own needs - they don't care about the general market or the size of the likely user segment. Producers, in contrast, must understand the general market potential and must believe there is some potential for profit before they will invest. Producers therefore enter markets later, profiting from information on designs, desired product functions, and potential market demand that emerge as a side effect of free innovator pioneering.

Supporting Free Innovator Development of Complements. Complements can be critical to the value of a product. For example, a specialized mountain bike is of little value to a biker who has not learned specialized mountain biking techniques. However, the complements themselves are not always commercially viable for producers; in those cases, companies rely on free innovators to provide the complement. Producers sell mountain bikes, for example, but rely on expert bikers to create and diffuse mountain biking techniques; bikers generally learn techniques from personal experimentation and from advice that more expert peers give them for free. The complements provided by free innovators both add value to the product and enable producers to focus on selling commercially viable products. Producers generally prefer that complements be supplied by free innovators, rather than by other producers, because free innovators typically do not seek to share in the profits that their complements create-leaving that potential for the producer to capture. 
Accessing Free Innovator Product Designs. Designs developed by free innovatorsboth at the start of new markets and during the evolution of existing markets—often spill over to producers and become the basis for valuable commercial products. For example, improvements to diabetic medical devices developed by the NightScout community have been profitably adopted by commercial producers of those devices. This is perhaps the most direct benefit of engaging with user communities, as adoption of designs developed by free innovators can greatly reduce in-house development costs (Franke and Shah 2003; Baldwin, Hienerth, and von Hippel 2006; Jeppesen and Frederiksen 2006; Lettl, Herstatt, and Gemuenden 2006).

Directing Free Innovator Efforts through Tools and Other Support. Even as forward-thinking producers adopt designs from free innovators, they also provide valuable information and support to free innovators. Why would they want to do this? Because by providing such tools and support, companies can direct free innovator innovation efforts in directions that are profitable to them and create a greater flow of valuable designs for their firm. For example, Valve, a video game development firm, offers game players access to a website, Steam Workshop, ${ }^{2}$ that is designed to support player innovation and interaction. The site, which is used by millions of game players and developers, offers tools and advice to help users to develop their own game modifications and improvements. The site also provides channels for gamers who innovate to share their developments with other players. Steam Workshop has generated tremendous benefits for both players-customers and Valve: It increases the supply of valuable designs for Valve, at little cost. It also creates a central posting place for free innovation activity, which allows Valve to observe the community closely and derive valuable insights beyond the designs themselves. Finally, because the game designs created by participating free innovators are specific to Valve-supported games, there is not a great deal of spillover of benefits from Steam to Valve's competitors (Jeppesen and Frederiksen 2006; Gambardella, Raasch, and von Hippel 2016).

Using Free Innovator Competition to Spur Internal Creativity. Although the profitenhancing potential of free innovation is a benefit to producers, the presence of free innovators would seem to offer a significant potential downside for producers in the competition they could represent. Free innovators, by definition, give away their designs, and it can sometimes be difficult for producers to compete with free. For example, Linux open-source software is available for free from the Linux development community, in a peer-to-peer sharing arrangement. Red Hat offers a close substitute at the same time, but at a price. In such cases, peer-to-peer diffusion via the free innovation paradigm competes with products and services that producers are selling on the market. This competitive force ultimately increases social welfare, by requiring producers to find ways to differentiate their offerings to avoid head-to-head competition with free offerings. Red Hat competes with free Linux distributions by offering better customer support for its operating system releases, as well as long-term bug-fixing services for earlier Linux releases; corporate users, who don't move from version to version as rapidly as the free innovators in Linux's development community, value these services highly. Similarly, many sports equipment designs are initially developed by free innovators and made available for free both to other adopters and to producers. In principle, the producers have a competitor in the form of DIY production by potential customers. However, economies 
of scale mean that it is often much cheaper for a consumer to buy a copy than to make one. In fact, although mountain biking grew out of free innovations, and free designs are fairly widely available, very few bikers build their own bikes today-it is much easier and cheaper to buy the designs from producers. This is another way that producers can compete effectively with free.

\section{Conclusion}

Producers have for too long ignored the valuable resource that consumer innovation activity represents. Both producers' profits and social welfare increase if producers learn to search systematically for these free designs and also to support the designers by creating platforms that allow innovating consumers to share their designs, with each other and with the company. As a side effect of supporting this activity, producers can learn which designs or features are most popular among potential customers and adopt those into their product offerings as appropriate. In essence, producers of consumer goods and services must learn to reorient their in-house product and service development activities to incorporate a planned division of labor with free innovators. They will benefit from doing so.

\section{References}

Antorini, Y. M., Muñiz Jr., A. M., and Askildsen, T. 2012. Collaborating with customer communities: Lessons from the Lego Group. Sloan Management Review 53(3): 73-79.

Baldwin, C. Y., Hienerth, C., and von Hippel, E. 2006. How user innovations become commercial products: A theoretical investigation and case study. Research Policy 35:1291-1313.

Mataloni, L. S. 2015. GDP and the economy: Second estimates for the third quarter of 2015. Survey of Current Business Online 95(12).

http://www.bea.gov/scb/pdf/2015/12\%20December/1215_gdp_and_the_economy .pdf

Franke, N., and Shah, S. 2003. How communities support innovative activities: An exploration of assistance and sharing among end-users. Research Policy 32:157178.

Franke, N., von Hippel, E., and Schreier, M. 2006. Finding commercially attractive user innovations: A test of lead-user theory. Journal of Product Innovation Management 23:301-315.

Gambardella, A., Raasch, C., and von Hippel, E. 2016. The user innovation paradigm: impacts on markets and welfare. Management Science, Articles in Advance, April 4. http://dx.doi.org/10.1287/mnsc.2015.2393 
Jeppesen, L. B., and Frederiksen, L. 2006. Why do users contribute to firm-hosted user communities? The case of computer-controlled music instruments. Organization Science 17(1): 45-63.

Lettl, C., Herstatt, C., and Gemuenden, H. G. 2006. Users' contributions to radical innovation: Evidence from four cases in the field of medical equipment technology. R\&D Management 36(3): 251-272.

Linebaugh, K. 2014. Citizen hackers tinker with medical devices. Wall Street Journal, September 26. http://www.wsj.com/articles/citizen-hackers-concoct-upgrades-formedical-devices-1411762843

OECD. 2015. National Accounts at a Glance 2015. Paris: OECD Publishing. http://dx.doi.org/10.1787/na_glance-2015-en

Oliveira, P., and von Hippel, E. 2011. Users as service innovators: The case of banking services. Research Policy 40:806-818.

von Hippel, E. 2017. Free Innovation. Cambridge, MA: MIT Press. Free electronic version available at https://evhippel.mit.edu/books/

von Hippel, E. A., de Jong, J. P. J., and Flowers, S. 2012. Comparing business and household sector innovation in consumer products: Findings from a representative survey in the United Kingdom. Management Science 58 (9): 1669-1681. 


\section{Notes}

1. This article offers a brief sketch of the concept and importance of free innovation. My book Free Innovation, released by MIT Press this month, provides much more detail.

2. 2. See http://steamcommunity.com/workshop/. 
Table 1.-Consumer innovators in six countries

\begin{tabular}{lcccccc}
\hline $\begin{array}{l}\text { Country } \\
(n)\end{array}$ & $\begin{array}{c}\text { UK } \\
(1173)\end{array}$ & $\begin{array}{c}\text { US } \\
(1992)\end{array}$ & $\begin{array}{c}\text { Japan } \\
(2,000)\end{array}$ & $\begin{array}{c}\text { Finland } \\
(993)\end{array}$ & $\begin{array}{c}\text { Canada } \\
(2,021)\end{array}$ & $\begin{array}{c}\text { South Korea } \\
(10,821)\end{array}$ \\
\hline $\begin{array}{l}\text { \% of consumers who engage in } \\
\text { consumer innovation }\end{array}$ & $6.1 \%$ & $5.2 \%$ & $3.7 \%$ & $5.4 \%$ & $5.6 \%$ & $1.5 \%$ \\
Number of consumer innovators & 2.9 million & 16.0 million & 4.7 million & 0.172 million & 1.6 million & 0.54 million \\
\hline Source: von Hippel (2017), Table 2-1, p.21 & & & & &
\end{tabular}

Note: Surveys included individuals over 18 years of age; individuals younger than 18 were excluded due to youth privacy concerns. In Finland, the age range of respondents was $18-65$ years. 


\section{figure captions}

Figure 1.- The free innovation and producer innovation paradigms 